\title{
Insect tea attenuates hydrochloric acid and ethanol-induced mice acute gastric injury
}

\author{
XIN ZHAO $^{1-4^{*}}$, QIANG CHENG ${ }^{5,6^{*}}$, YU QIAN $^{3-6}$, RUOKUN YI $^{3-6}$, \\ LIANJIE GU $^{1}$, SHANSHAN WANG ${ }^{1}$ and JIA-LE SONG ${ }^{1,5,6}$
}

\begin{abstract}
${ }^{1}$ Chongqing Collaborative Innovation Center for Functional Food; ${ }^{2}$ Chongqing Engineering Research Center of Functional Food; ${ }^{3}$ Chongqing Engineering Laboratory for Research and Development of Functional Food; ${ }^{4}$ Department of Food Quality and Safety, Chongqing University of Education, Chongqing 400067; ${ }^{5}$ Department of Nutrition and Food Hygiene, School of Public Health; ${ }^{6}$ Institute of Preventive Medicine, Guilin Medical University, Guilin, Guangxi 541004, P.R. China
\end{abstract}

Received October 10, 2016; Accepted June 22, 2017

DOI: $10.3892 / \mathrm{etm} .2017 .5181$

\begin{abstract}
The aim of the present study was to investigate the protective effect of insect tea on $\mathrm{HCl} /$ ethanol-induced gastric ulcers in ICR mice. The serum levels of vasoactive intestinal peptide, substance $\mathrm{P}$, somatostatin, motilin and endothelin-1 in mice were assessed using commercial kits and gastric tissues of superoxide dismutase (SOD, nitric oxide (NO) and malondialdehyde (MDA) were determined using western blot analysis Insect tea significantly reduced $\mathrm{HCl} /$ ethanol-induced gastric juice secretion and increased the $\mathrm{pH}$ of gastric juice $(\mathrm{P}<0.05)$. Insect tea treatment signfiicantly increased vasoactive intestinal peptide and somatostatin, and significantly decreased motilin, substance $\mathrm{P}$ and endothelin levels in the serum $(\mathrm{P}<0.05)$. Treatment with insect tea was demonstrated to significantly increase levels of gastric SOD and NO and to reduce levels of MDA in the gastric ulcer mouse model $(\mathrm{P}<0.05)$. The gastric expression of inhibitor of nuclear factor- $\mathrm{kB}(\mathrm{NF}-\kappa \mathrm{B})$, epidermal growth factor (EGF), EGF receptor, neuronal nitric oxide synthase (nNOS), endothelial NOS, Mn-SOD, Cu/Zn-SOD and catalase was significantly increased in mice treated with inset tea compared with untreated model mice $(\mathrm{P}<0.05)$. Levels of NF- $\kappa \mathrm{B}$, and inducible NOS were demonstrated to be decreased in mice treated with insect tea compared with untreated model mice $(\mathrm{P}<0.05)$. The results of the present study suggest that insect tea has a protective effect against $\mathrm{HCl} /$ ethanol-induced gastric ulcers
\end{abstract}

Correspondence to: Professor Jia-Le Song, Department of Nutrition and Food Hygiene, School of Public Health, Guilin Medical University, 109 Huancheng North Road, Guilin, Guangxi 541004, P.R. China

E-mail: foods@live.cn

${ }^{*}$ Contributed equally

Abbreviations: VIP, vasoactive intestinal peptide; SP, substance P; SS, somatostatin; MOT, motilin; ET-1, endothelin-1

Key words: insect tea, mice, acute gastric injury, expression in ICR mice. This effect may be achieved via modulating serum neuropeptide levels, reducing gastric juice secretion, and modulating the inflammation- and antioxidant-associated protein expressions in gastric tissue.

\section{Introduction}

Imbalances in offensive factors (including acid, pepsin, and Helicobacter pylori infection) and defensive factors (including mucin, prostaglandin, bicarbonate, nitric oxide, and growth factors) serve an important role in the pathology of chronic gastric ulcers, which are associated with the development of gastric cancer (1). The prevalence of chronic gastric disease, in particular gastric ulcers, is increasing (2); however, the etiology is currently unclear. Lifestyle factors, including alcohol consumption, tobacco use and stress, are widely accepted as causative factors in the pathogenesis of chronic gastric ulcers (2).

Neuropeptides are a type of small protein-like molecule that are associated with a wide range of brain functions and have also been demonstrated to regulate gastric juice secretion, motility and contractions (3). These neuropeptides, including vasoactive intestinal peptide (VIP), substance $P$ (SP), somatostatin (SS), motilin (MOT) and endothelin-1 (ET-1), are widely distributed in the gastrointestinal tract and modulate the immune reaction in the intestinal mucosa $(3,4)$. Abnormal levels of these neuropeptides have previously been observed in patients with gastrointestinal mucosal lesions and hemorrhage (5).

At present, the primary clinical treatment for gastric ulcers is the administration of histamine- 2 receptors antagonist (including cimetidine and ranitidine) or proton-pump inhibitors (including lansoprazole) to reduce gastric juice secretion (6). However, long-term use of these agents may cause serious side effects, including hypergastrinemia, nausea, abdominal pain, constipation, diarrhea and increased risk of hip fracture (7). Therefore, the development of more effective pharmacological agents to treat gastric ulcers with fewer side effects is of great importance.

Insect tea, which is produced using insect feces, is a traditional drink that has long been used by ethnic minorities 
in southwest China (8). Insect tea contains no tea leaves, rather the name is derived from the color of the drink (9). A number of previous studies have reported that insect tea has health benefits, including anticancer $(8,10)$, antioxidant $(11)$, hypoglycemic and antihypertensive effects (8). Insect tea has also been reported to reduce inflammation-induced colonic mucosa injury and promote duodenal motility activity (8). The aim of the present study was to investigate the potential protective effect of insect tea on the gastrointestinal tract and to elucidate the mechanisms underlying these effects using $\mathrm{HCl} /$ ethanol-induced gastric ulcers in mice.

\section{Materials and methods}

Preparation of raw tea and insect tea aqueous extracts. Fresh raw tea (Ilex kudingcha $\mathrm{C}$. J. Tseng) and insect tea were purchased from Guizhou Chishui Green Ecology Industry Co., Ltd. (Zunyi, China), freeze-dried and subsequently ground into separate fine powders, the raw tea (Kuding tea) and insect tea was identified by Professor Huayi Suo (Southwest University, Chongqing, China). Powdered samples (1 kg) were added to $10 \mathrm{l}$ ethanol $\left(70 \%\right.$, vol/vol) and extracted at $37^{\circ} \mathrm{C}$ for $2 \mathrm{~h}$. Each solution was filtered and condensed using a vacuum rotary evaporator (1,490 x g for $10 \mathrm{~min}$ ) (Eyela N-1100V-W; Tokyo Rikakikai Co. Ltd, Tokyo, Japan) at $37^{\circ} \mathrm{C}$, freeze-dried and stored at $-80^{\circ} \mathrm{C}$ for further experiments.

Amino acid assay. A total of $800 \mathrm{mg}$ of each type of tea was mixed with $3 \mathrm{ml}$ sulfosalicylic acid solution $(6 \%$, w/v; Shanghai Zhanyun Chemical Company Limited, Shanghai, China), sonicated $(26 \mathrm{kHz})$ for $60 \mathrm{~min}$ at $37^{\circ} \mathrm{C}$ and cooled to $4^{\circ} \mathrm{C}$ for $12 \mathrm{~h}$. The extract was centrifuged at $13,000 \mathrm{x} \mathrm{g}$ for $2 \mathrm{~min}$ at $4^{\circ} \mathrm{C}$ and filtered using a $0.45-\mu \mathrm{m}$ milliporefilter (EMD Millipore, Billerica, MA, USA). The amino acids in raw tea and insect tea were determined using an automatic amino acid analyzer (L-8800; Hitachi, Ltd., Tokyo, Japan) equipped with a Hitachi Packed Column (2620MSC-PS; inner diameter, $4.6 \mathrm{~mm}$; length, $80 \mathrm{~mm}$ ) filled with a $\mathrm{Na}^{+}$-form sulfonic resin (Langfang Miaoyang Chemical Company Limited, Langfang, China). The amount of total amino acids were identified and quantified against a standard compound based on its retention time and peak areas. The amino acid standards were purchased from National Institute for Food and Drug Control (Beijing, China).

Animal groups and acute gastric ulcer induction. A total of 35 male ICR mice (6 weeks old, 25-30 g) were purchased from the Experimental Animal Center of Chongqing Medical University (Chongqing, China). Mice were housed with a standard 12 -h light/dark cycle at $23 \pm 1^{\circ} \mathrm{C}$ with relative humidity $50 \pm 5 \%$ and had ad libitum access to food and water. Mice were randomly divided into five groups $(n=7$ in each) and treated as follows: Group 1 (normal group), administered $0.9 \%$ normal saline; group 2 (control group), $\mathrm{HCl} /$ ethanol $(0.1 \mathrm{ml}$ $\mathrm{HCl}$ or ethanol per $10 \mathrm{~g} ; 60 \%$ in $150 \mathrm{mM} \mathrm{HCl}$ on the last day); group 3 (raw tea group), $\mathrm{HCl} /$ ethanol-treated mice administered with raw tea $(100 \mathrm{mg} / \mathrm{kg} /$ day for 28 days $)$ and group 4 (insect tea group), $\mathrm{HCl} / \mathrm{ethanol-treated} \mathrm{mice} \mathrm{administered}$ with insect tea $(100 \mathrm{mg} / \mathrm{kg} /$ day for 28 days; group 5 (ranitidine), $\mathrm{HCl} /$ ethanol-treated mice administered with ranitidine
(50 mg/kg/day for 28 days, Sigma-Aldrich; Merck KGaA, Darmstadt, Germany). All treatments were administered via oral gavage. On experimental day 29, all mice had developed jejunitis and were denied food but allowed to drink water ad libitum. Mice in groups 3, 4 and 5 were gavaged with a stomach injury inducer $(0.1 \mathrm{ml} \mathrm{HCl}$ or ethanol per $10 \mathrm{~g} ; 60 \%$ in $150 \mathrm{mM} \mathrm{HCl}$ ) on day 30 and sacrificed after $1 \mathrm{~h}$ (12). Blood samples were harvested from the inferior vena cava, centrifuged at $3,000 \mathrm{x}$ g for $10 \mathrm{~min}$ at $4^{\circ} \mathrm{C}$ and stored at $-80^{\circ} \mathrm{C}$ until required for further study. The animal protocol used in the present study was approved by the Animal Ethics Committee of Chongqing University of Education.

Evaluation of antiulcer activity. The volume of gastric secretions from each mouse was measured with a $10-\mathrm{ml}$ measuring cylinder following sacrifice and the $\mathrm{pH}$ of gastric juice was determined using a SevenEasy $\mathrm{pH}$ meter (Mettler Toledo GmbH, Greifensee, Switzerland). The stomachs were harvested using hemostatic forceps, and the isolated stomachs were inflated by injecting $10 \mathrm{ml} 1 \%$ formalin solution for $10 \mathrm{~min}$ to fix the tissues at $25^{\circ} \mathrm{C}$ and opened along the greater curvature. Gastric tissue was observed using digital camera (D550; Canon, Tokyo, Japan), and the gastric injury area was measured using ImageJ 1.44 software (National Institutes of Health, Bethesda, MD, USA). The gastric injury inhibitory rate $(\%)=(1$ - gastric injury area of sample treated mice / gastric injury area of control mice) x 100 .

Measurement of gastric neuropeptide levels. Serum levels of MOT (H182; MOT assay kit), SP (H218; substance P assay kit), VIP (H219; vasoactive intestinal peptide assay kit), SS (H092; somatostatin assay kit) and ET-1 (H093; endothelin-1 assay kit) were measured with radioimmunoassay kits (all Beijing Puer Weiye Biotechnology Co., Ltd., Beijing, China) according to the manufacturer's protocols.

Measurement of superoxidase (SOD), nitric oxide (NO) and malondialdehyde (MDA) in gastric tissue. Gastric levels of SOD (A001-3), NO (A012) and MDA (A003-1) were respectively measured using commercial ELISA kits (Nanjing Jiancheng Bioengineering Institute, Nanjing, Jiangsu, China) according to the manufacturer's protocols.

Protein extraction and western blot analysis. A total of $100 \mathrm{mg}$ gastric tissue was washed with ice-cold PBS, homogenized with ice-cold modified radioimmunoprecipitation assay buffer (Sigma-Aldrich; Merck KGaA) and centrifuged at 13,000 x g for $30 \mathrm{~min}$ at $4^{\circ} \mathrm{C}$. Protein concentrations were determined using a bicinchoninic acid protein assay kit (Bio-Rad Laboratories, Inc., Hercules, CA, USA). For western blot analysis, $50 \mu \mathrm{g}$ protein extracts were separated by $10 \%$ SDS-PAGE and electrotransferred onto a nitrocellulose membrane. The membrane was blocked with $10 \%$ skimmed milk at $4^{\circ} \mathrm{C}$ for $8 \mathrm{~h}$. Blots were subsequently incubated with antibodies against

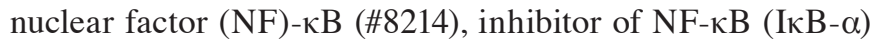
(\#8219), epidermal growth factor (EGF) (\#2237), EGF receptor (EGFR) (\#11862), endothelial nitric oxide synthase (eNOS) (\#32027), neuronal NOS (nNOS) (\#4231), inducible NOS (iNOS) (\#13120), Mn-SOD (\#13141), Cu/Zn-SOD (\#4266), catalase (CAT) (\#14097) and $\beta$-actin (\#12262) (all 1:5,000; all 
Cell Signaling Technology, Inc., Danvers, MA, USA) for $4 \mathrm{~h}$ at $4^{\circ} \mathrm{C}$. Membranes were washed with PBS (3 times for $15 \mathrm{~min}$ ) containing $0.05 \%$ Tween 20 (PBS-T) and subsequently incubated with horseradish peroxidase-conjugated goat-anti-rabbit or anti-mouse immunoglobulin G (\#14709; 1:1,000; Cell Signaling Technology, Inc.) for $1 \mathrm{~h}$ at room temperature. Blots were washed three times with PBS-T (3 times for $15 \mathrm{~min}$ ) and antibody binding was visualized by enhanced chemiluminescence (ECL Western Blotting Detection kit; GE Healthcare Life Sciences, Little Chalfont, UK). Protein expression was quantified using ImageJ 1.44 software (National Institutes of Health).

Statistical analysis. Data are presented as the mean \pm standard deviation. Differences between groups were assessed using one-way analysis of variance with Duncan's multiple range tests. The SAS v9.1 statistical software package (SAS Institute, Inc., Cary, NC, USA) was used for the analysis. $\mathrm{P}<0.05$ was considered to indicate a statistically significant difference.

\section{Results}

Accumulation of amino acids in insect tea. The amino acid contents of raw tea and insect tea as determined by an automatic amino acid analyzer are presented in Fig. 1 and Table I. Compared with the raw tea, insect tea contained a markedly higher level of total amino acids. The insect tea also contained higher levels of human essential amino acids including threonine, valine, isoleucine, phenylalanine and lysine. However, levels of methionine and leucine were lower in insect tea compared with raw tea. Furthermore, tryptophan was not detected in either of the preparations, and insect tea contained higher levels of glutamate, arginine and proline compared with raw tea.

Insect tea attenuates HCl/ethanol-induced gastric ulcer. $\mathrm{HCl} /$ ethanol treatment significantly induced the formation of gastric ulcers and bleeding in mice $(\mathrm{P}<0.05$; Fig. 2 and Table II). Administration of $100 \mathrm{mg} / \mathrm{kg}$ raw tea or insect tea significantly reduced area of $\mathrm{HCl} /$ ethanol-induced acute gastric ulcer in mice $(\mathrm{P}<0.05$; Table II); the level of inhibition was $56.3 \%$ (gastric ulcer area, $3.65 \pm 0.43 \mathrm{~mm}^{2}$ ) and $72.1 \%$ (gastric ulcer area, $2.33 \pm 0.48 \mathrm{~mm}^{2}$ ) with raw tea and insect tea treatment, respectively. These results suggest that the two treatments exhibited a significant protective effect against $\mathrm{HCl} /$ ethanol-induced gastric ulcers; however, their effect was weaker than that observed in ranitide-treated mice (gastric ulcer area, $1.05 \pm 0.27 \mathrm{~mm}^{2}$; inhibition, 87.4\%). In addition, $\mathrm{HCl} /$ ethanol treatment significantly increased gastric juice secretion compared with normal mice $(\mathrm{P}<0.05$; Table II). Following the administration of $100 \mathrm{mg} / \mathrm{kg}$ raw tea or insect tea for 28 days, gastric juice secretion was significantly reduced compared with the control group $(\mathrm{P}<0.05$; Table II). Raw tea and insect tea treatment also significantly increased the $\mathrm{pH}$ of gastric juice compared with control mice $(\mathrm{P}<0.05$; Table II). All mice in all groups survived the total experimental period.

Effect of insect tea on serum neuropeptide levels in HCl/ethanol-induced gastric ulcer mice. $\mathrm{HCl} / \mathrm{ethanol}$ treatment was observed to significantly increase the acute gastric ulcer-related serum neuropeptide levels of MOT, SP
Table I. Amino acid components of raw tea and insect tea.

\begin{tabular}{lcc}
\hline & \multicolumn{2}{c}{ Content $(\mathrm{mg}$ per $100 \mathrm{~g})$} \\
\cline { 2 - 3 } Amino acid & Raw tea & Insect tea \\
\hline Aspartate & 0.329 & 0.315 \\
Threonine & 0.320 & 0.785 \\
Serine & 0.219 & 0.166 \\
Glutamate & 0.660 & 1.454 \\
Glycine & 0.227 & 0.146 \\
Alanine & 1.241 & 0.532 \\
Cysteine & 0.772 & 0.539 \\
Valine & 0.494 & 1.525 \\
Methionine & 0.407 & 0.000 \\
Isoleucine & 0.000 & 0.077 \\
Leucine & 0.244 & 0.123 \\
Tyrosine & 2.806 & 0.249 \\
Phenylalanine & 0.903 & 2.122 \\
Lysine & 0.534 & 0.550 \\
Histidine & 0.000 & 0.000 \\
Arginine & 0.457 & 5.280 \\
Proline & 0.294 & 1.478 \\
Total amino acids & 33.414 & 34.159 \\
\hline
\end{tabular}

and ET-1 compared with normal mice $(\mathrm{P}<0.05$; Table III). Administration of $100 \mathrm{mg} / \mathrm{kg}$ raw tea or insect tea significantly attenuated the serum levels of MOT, SP and ET-1 compared with control mice $(\mathrm{P}<0.05$; Table III). In addition, treatment with raw tea or insect tea significantly increased the serum levels of SS and VIP compared with the control group $(\mathrm{P}<0.05$; Table III). Furthermore, the results indicated that insect tea modulated the neuropeptide levels to a greater extent than raw tea (Table III).

Effect of insect tea on gastric levels of SOD, NO and MDA in $\mathrm{HCl}$ ethanol-induced gastric ulcer mice. $\mathrm{HCl} /$ ethanol treatment significantly reduced the gastric activity of the antioxidant enzyme SOD (69\%) and significantly induced the lipid peroxidation related MDA generation (5.0-fold) compared with normal mice ( $\mathrm{P}>0.05$; Table IV). Treatment with $100 \mathrm{mg} / \mathrm{kg}$ raw tea or insect tea significantly increased the levels of SOD (to $225.6 \pm 31.2$ and $291.6 \pm 25.5 \mathrm{kU} / 1$, respectively) and $\mathrm{NO}$ (to $8.2 \pm 0.4$ and $12.2 \pm 0.4 \mu \mathrm{mol} / 1$, respectively) compared with control mice $(\mathrm{P}<0.05$; Table IV). In addition, raw tea and insect tea significantly reduced MDA generation compared with the control group $(\mathrm{P}<0.05$; Table IV). Raw tea had a weaker effect in regulating antioxidant activity compared with insect tea (Table IV).

Effect of insect tea on the gastric expression of Mn-SOD, Cu/Zn-SOD, and CAT in HCl/ethanol-induced gastric ulcer mice. In $\mathrm{HCl} /$ ethanol-treated mice, the gastric levels of Mn-SOD, Cu/Zn-SOD, and CAT were significantly decreased compared with that in normal mice $(\mathrm{P}<0.05$; Fig. 3$)$. Mice treated with $100 \mathrm{mg} / \mathrm{kg}$ raw tea or insect tea exhibited significant increases in the gastric levels of Mn-SOD, Cu/Zn-SOD, 

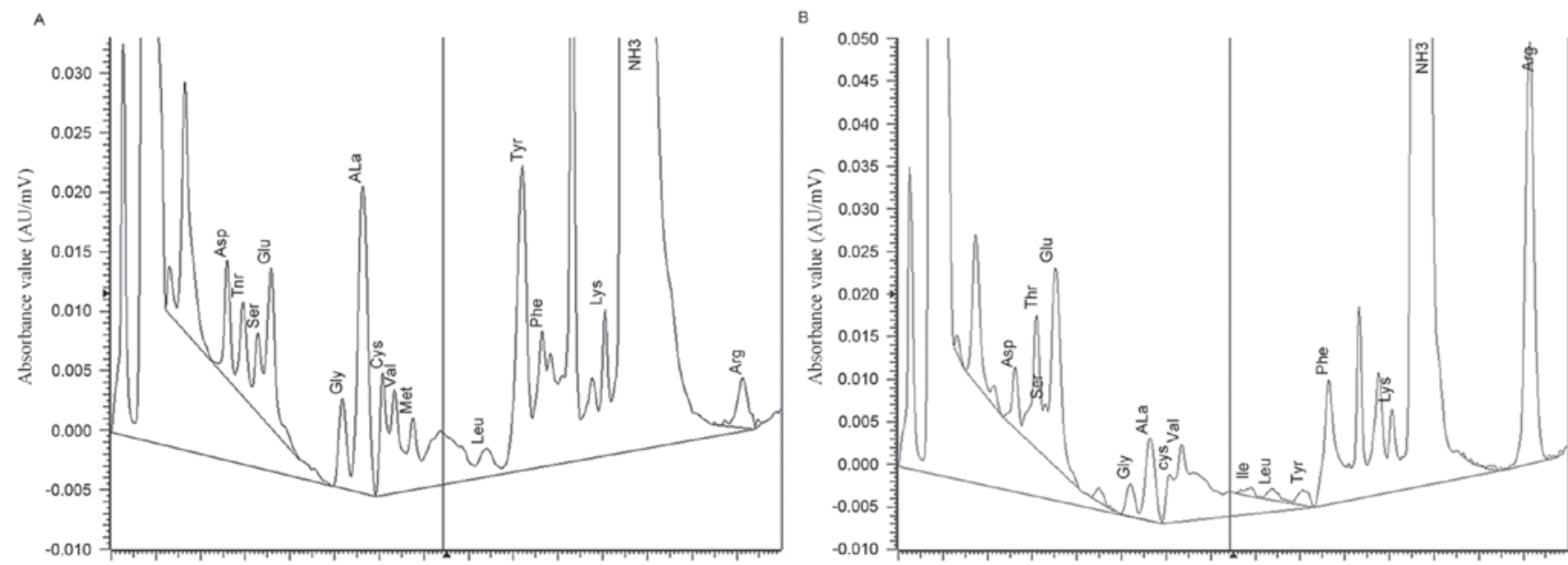

Figure 1. Amino acids spectrogram of (A) raw tea and (B) insect tea. AU, absorbance unit.

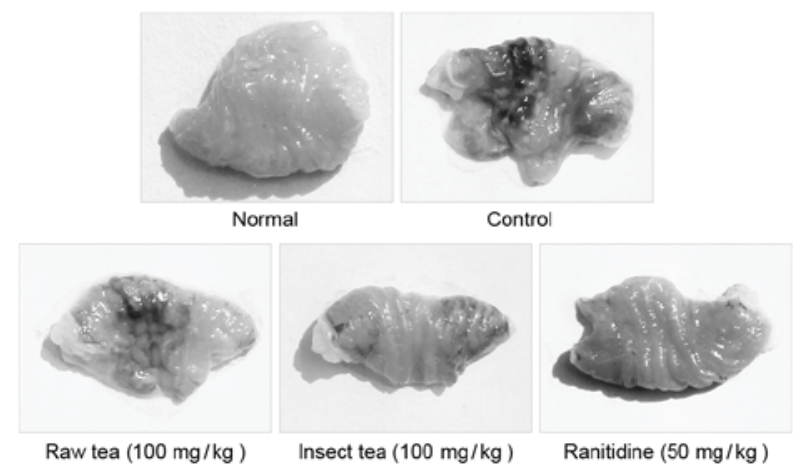

Figure 2. Representative stomachs from each treatment group. Darker areas indicate ulcer formation.

and CAT compared with the control mice $(\mathrm{P}<0.05$; Fig. 3$)$. $\mathrm{SOD}, \mathrm{Cu} / \mathrm{Zn}-\mathrm{SOD}$ and CAT protein expression were significantly higher in the gastric tissue of insect tea treated mice compared with raw tea treated mice. $(\mathrm{P}<0.05$; Fig. 3$)$.

Effect of insect tea on the gastric expression of nNOS, eNOS, and iNOS in HCl/ethanol-induced gastric ulcer mice. $\mathrm{HCl} /$ ethanol treatment significantly increased gastric iNOS expression and significantly decreased gastric nNOS and eNOS expression compared with normal mice ( $\mathrm{P}<0.05$; Fig. 4). However, mice treated with $100 \mathrm{mg} / \mathrm{kg}$ raw tea or insect tea were demonstrated to have significantly lower iNOS protein expression compared with control mice $(\mathrm{P}<0.05$; Fig. 4). Furthermore, mice in the raw tea and insect tea groups exhibited significant increases in levels of nNOS and eNOS compared with control mice $(\mathrm{P}<0.05$; Fig. 4). Furthermore, nNOS and eNOS protein expression in gastric tissue of insect tea treated mice was significantly higher compared with raw tea treated mice $(\mathrm{P}<0.05$; Fig. 4$)$.

Effect of insect tea on the gastric expression of $N F-\kappa B, I \kappa B-\alpha$, EGF and EGFR in HCl/ethanol-induced gastric ulcer mice. $\mathrm{HCl} /$ ethanol treatment significantly increased the expression of gastric NF-kB compared with normal mice ( $\mathrm{P}<0.05$; Fig. 5 ). Treatment with raw tea or insect tea significantly reduced the levels of NF-кB compared with control mice, and tea samples also significantly increased the gastric IкB- $\alpha$ expression compared with control mice ( $\mathrm{P}<0.05$; Fig. 5$)$. Levels of EGF and its receptor EGFR were significantly downregulated in $\mathrm{HCl} /$ ethanol-treated mice compared with the normal group (P>0.05; Fig. 5). However, EGF and EGFR were significantly increased in the raw tea and insect tea groups compared with the control group $(\mathrm{P}<0.05$; Fig. 5). In the insect tea group, levels of IкB- $\alpha$, EGF and EGFR were significantly higher and $\mathrm{NF}-\kappa \mathrm{B}$ expression was significantly lower compared with the raw tea group $(\mathrm{P}<0.05$; Fig. 5).

\section{Discussion}

Insect tea is a type of non-Camellia tea with a long history in China (8). Previous studies have reported that insect tea contains high levels of amino acids $(13,14)$. In the present study, it was demonstrated that insect tea contains higher levels of human essential amino acids (such as threonine, valine, isoleucine, phenylalanine, and lysine) compared with raw tea. Glutamate and its derivative, proglumide, have been reported to have anticholinergic effects as gastrin receptor antagonists that decrease gastric acid secretion and have a healing effect on gastric ulcers (15). Arginine is a substrate for nitric oxidesynthase and has previously exhibited gastroprotective and ulcer healing effects in animal and human studies (16-18). The amino acids leucine, isoleucine and valine constitute a branched-chain amino acid (BCAA), which is an amino acid with aliphatic side-chains (19). BCAAs have been reported to have therapeutic effects, promoting muscle and wound healing in a previous animal study (20). In the present study, it was demonstrated that insect tea treatment increased the $\mathrm{pH}$ of gastric juice in $\mathrm{HCl} /$ ethanol-treated mice. Maintaining a higher gastric juice $\mathrm{pH}$ reduces the activity of pepsin, which is a risk factor for gastric ulcers $(21,22)$, and improves healing of the gastric mucosa (23).

Excess gastric acid secretion is an important risk factor that promotes the development of gastric ulcers $(24,25)$, and reducing gastric juice secretion is a useful strategy to prevent and treat gastric ulcers (5). Gastric juice secretion is regulated by the central nervous system (CNS), in particular 
Table II. Stomach appearance, gastric secretion volume, and $\mathrm{pH}$ of gastric juice of insect tea treated $\mathrm{HCl} / \mathrm{ethanol}$-induced gastric injury mice.

\begin{tabular}{lcccc}
\hline & \multicolumn{2}{c}{ Gastric mucosal injury } & & \\
\cline { 2 - 3 } Group & Area $\left(\mathrm{mm}^{2}\right)$ & Inhibitory rate $(\%)$ & Gastric secretion volume $(\mathrm{ml})$ & Gastric juice $\mathrm{pH}$ \\
\hline Normal & $0.0 \pm 0.0$ & $100 \pm 0.0$ & $0.28 \pm 0.04$ & $3.5 \pm 0.1$ \\
Control & $8.35 \pm 0.81^{\mathrm{a}}$ & $0.0 \pm 0.0^{\mathrm{a}}$ & $1.87 \pm 0.36^{\mathrm{a}}$ & $1.0 \pm 0.2^{\mathrm{a}}$ \\
Raw tea & $3.65 \pm 0.43^{\mathrm{a}, \mathrm{b}}$ & $56.3 \pm 4.1^{\mathrm{a}, \mathrm{b}}$ & $0.85 \pm 0.16^{\mathrm{a}, \mathrm{b}}$ & $2.4 \pm 0.2^{\mathrm{a}, \mathrm{b}}$ \\
Insect tea & $2.33 \pm 0.48^{\mathrm{a}-\mathrm{c}}$ & $72.1 \pm 4.4^{\mathrm{a}-\mathrm{c}}$ & $0.60 \pm 0.11^{\mathrm{a}-\mathrm{c}}$ & $2.9 \pm 0.2^{\mathrm{a}-\mathrm{c}}$ \\
Ranitidine & $1.05 \pm 0.27^{\mathrm{a}-\mathrm{d}}$ & $87.4 \pm 2.2^{\mathrm{a}-\mathrm{d}}$ & $0.36 \pm 0.07^{\mathrm{a}-\mathrm{d}}$ & $3.3 \pm 0.3^{\mathrm{a}-\mathrm{d}}$ \\
\hline
\end{tabular}

Data are presented as the mean \pm standard deviation $(\mathrm{n}=7)$. ${ }^{\mathrm{a}} \mathrm{P}<0.05$ vs. normal, ${ }^{\mathrm{b}} \mathrm{P}<0.05$ vs. control, ${ }^{\mathrm{c}} \mathrm{P}<0.05$ vs. raw tea and ${ }^{\mathrm{d}} \mathrm{P}<0.05$ vs. insect tea

Table III. Serum MOT, SS, SP, VIP and ET-1 levels of Insect tea treated HCl/ethanol-induced gastric injury mice.

\begin{tabular}{|c|c|c|c|c|c|}
\hline Group & MOT $(\mu \mathrm{g} / \mathrm{l})$ & $\mathrm{SS}(\mu \mathrm{g} / \mathrm{l})$ & $\mathrm{SP}(\mu \mathrm{g} / \mathrm{l})$ & $\mathrm{VIP}(\mu \mathrm{g} / \mathrm{l})$ & ET-1 $(\mu \mathrm{g} / \mathrm{l})$ \\
\hline Normal & $48.2 \pm 2.6$ & $133.0 \pm 15.3$ & $57.1 \pm 2.9$ & $110.6 \pm 9.7$ & $66.9 \pm 1.8$ \\
\hline Control & $131.3 \pm 13.1^{\mathrm{a}}$ & $48.2 \pm 6.3^{\mathrm{a}}$ & $137.9 \pm 18.2^{\mathrm{a}}$ & $52.3 \pm 2.2^{\mathrm{a}}$ & $105.6 \pm 5.1^{\mathrm{a}}$ \\
\hline Raw tea & $89.5 \pm 7.2^{\mathrm{a}, \mathrm{b}}$ & $92.6 \pm 4.8^{a, b}$ & $101.2 \pm 7.3^{\mathrm{a}, \mathrm{b}}$ & $80.9 \pm 5.2^{\mathrm{a}, \mathrm{b}}$ & $86.6 \pm 1.1^{\mathrm{a}, \mathrm{b}}$ \\
\hline Insect tea & $66.3 \pm 4.2^{\mathrm{a}-\mathrm{c}}$ & $107.5 \pm 4.0^{\mathrm{a}-\mathrm{c}}$ & $80.6 \pm 4.8^{\mathrm{a}-\mathrm{c}}$ & $91.2 \pm 4.7^{\mathrm{a}-\mathrm{c}}$ & $78.9 \pm 2.3^{\mathrm{a}-\mathrm{c}}$ \\
\hline Ranitidine & $55.6 \pm 2.3^{\mathrm{a}-\mathrm{d}}$ & $122.5 \pm 6.1^{\mathrm{a}-\mathrm{d}}$ & $68.9 \pm 2.6^{\mathrm{a}-\mathrm{d}}$ & $101.2 \pm 2.1^{\mathrm{a}-\mathrm{d}}$ & $72.5 \pm 1.6^{\mathrm{a}-\mathrm{d}}$ \\
\hline
\end{tabular}

Data are presented as the mean \pm standard deviation $(\mathrm{n}=7)$. ${ }^{\mathrm{a}} \mathrm{P}<0.05$ vs. normal, ${ }^{\mathrm{b}} \mathrm{P}<0.05$ vs. control, ${ }^{\mathrm{c}} \mathrm{P}<0.05$ vs. raw tea and ${ }^{\mathrm{d}} \mathrm{P}<0.05$ vs. insect tea. MOT, motilin; SS, somatostatin; SP, substance P; VIP, vasoactive intestinal peptide; ET-1, endothelin-1.

Table IV. Gastric tissues SOD, NO and MDA activities of insect tea treated $\mathrm{HCl} /$ ethanol-induced gastric injury mice.

\begin{tabular}{llcl}
\hline Group & SOD $(\mathrm{kU} / \mathrm{l})$ & $\mathrm{NO}(\mu \mathrm{mol} / \mathrm{l})$ & $\operatorname{MDA}(\mu \mathrm{mol} / \mathrm{l})$ \\
\hline Normal & $347.9 \pm 40.5$ & $15.2 \pm 0.3$ & $17.8 \pm 2.1$ \\
Control & $107.1 \pm 24.3^{\mathrm{a}}$ & $3.1 \pm 0.2^{\mathrm{a}}$ & $89.2 \pm 4.2^{\mathrm{a}}$ \\
Raw tea & $225.6 \pm 31.2^{\mathrm{a}, \mathrm{b}}$ & $8.2 \pm 0.4^{\mathrm{a}, \mathrm{b}}$ & $50.2 \pm 3.6^{\mathrm{a}, \mathrm{b}}$ \\
Insect tea & $291.6 \pm 25.5^{\mathrm{a}-\mathrm{c}}$ & $12.2 \pm 0.4^{\mathrm{a}-\mathrm{c}}$ & $32.5 \pm 2.3^{\mathrm{a}-\mathrm{c}}$ \\
Ranitidine & $321.3 \pm 22.6^{\mathrm{a}-\mathrm{d}}$ & $13.8 \pm 0.3^{\mathrm{a}-\mathrm{d}}$ & $24.7 \pm 1.8^{\mathrm{a}-\mathrm{d}}$ \\
\hline
\end{tabular}

Data are presented as the mean \pm standard deviation $(\mathrm{n}=7)$. ${ }^{\mathrm{a}} \mathrm{P}<0.05$ vs. normal, ${ }^{b} \mathrm{P}<0.05$ vs. control, ${ }^{\mathrm{c}} \mathrm{P}<0.05$ vs. raw tea and ${ }^{\mathrm{d}} \mathrm{P}<0.05$ vs. insect tea. SOD, superoxide dismutase; NO, nitric oxide; MDA, malondialdehyde.

the vagus nerve system (26). Neuropeptides are able to influence CNS activity and maintain gastric mucosal homeostasis (3). Some neuropeptides, including SP, MOT, SP, VIP and ET-1, are associated with the regulation of gastric acid secretion and serve important roles in gastric tissue repair under normal physiological conditions (27). In the present study, it was observed that administration of $100 \mathrm{mg} / \mathrm{kg}$ insect tea significantly decreased serum levels of SP, MOT and ET-1 in gastric ulcer mice. SP stimulates gastric juice secretion (28) and decreases gastric contractions (29), resulting in delayed gastric emptying and aggravating gastric ulcers in patients with gastritis $(30,31)$. MOT is a powerful inducer of gastrointestinal motor activity (32) and intestinal contractilities, and stimulates the secretion of human gastric pepsin $(33,34)$. ET-1 is a potent vasoconstrictor that is produced by vascular endothelial cells (35). Submucosal injections of ET-1 have previously been demonstrated to induce gastric ulcers in rats (36). Increased levels of ET-1 have previously been observed in critically ill patients with stress ulcers (37). Increased ET-1 generation is associated with the progression of gastric mucosal injury in rodent models, and inhibiting ET-1 activity has been demonstrated to reduce chemically-induced gastric ulcers $(38,39)$. In the present study, it was demonstrated that the administration of $100 \mathrm{mg} / \mathrm{kg}$ insect tea significantly increased serum levels of SS and VIP in gastric ulcer mice. SS is a type of amino acid peptide that is distributed in the brain and the peripheral organs (3) and is able to inhibit chemically (pentagastrin, bethanechol, or histamine)-induced gastric acid secretion in rats via activating somatostatin type 2 receptors (40-42). Peripheral injection of VIP has been demonstrated to decrease gastric acid secretion via inhibiting vagus nerve activation in rats $(43,44)$. This suggests that insect tea may influence gastric juice secretion in $\mathrm{HCl} /$ ethanol-induced gastric ulcers by increasing the serum levels of VIP and SS, as well as reducing the serum levels of SP, MOT and ET-1.

Chemically-induced or ischemia-associated overgeneration of reactive oxygen species (ROS) results in lipid peroxidation 

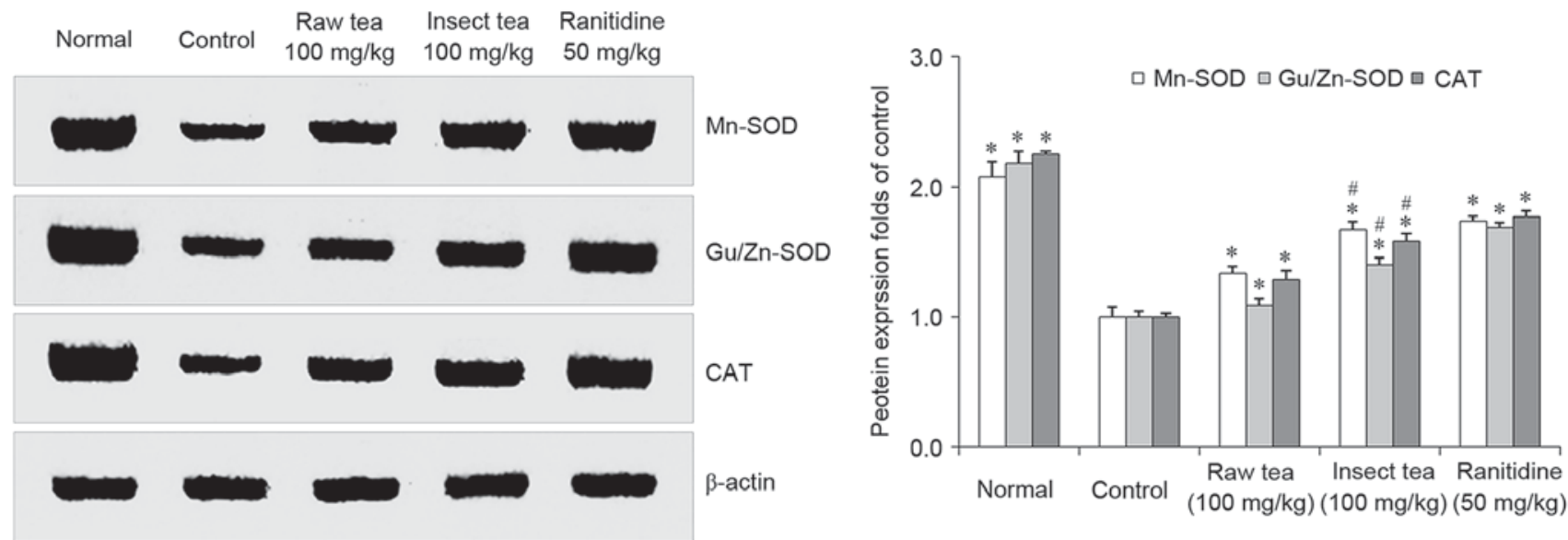

Figure 3. Effect of insect tea on $\mathrm{Mn}-\mathrm{SOD}, \mathrm{Cu} / \mathrm{Zn}$-SOD and CAT protein expression in $\mathrm{HCl} /$ ethanol-induced gastric mucosal injury mice. Data are relative to the control group and are presented as the mean + standard deviation $(n=7) .{ }^{*} \mathrm{P}<0.05$ vs. control, ${ }^{\prime \prime} \mathrm{P}<0.05$ vs. raw tea. SOD, superoxide dismutase; $\mathrm{CAT}$, catalase.
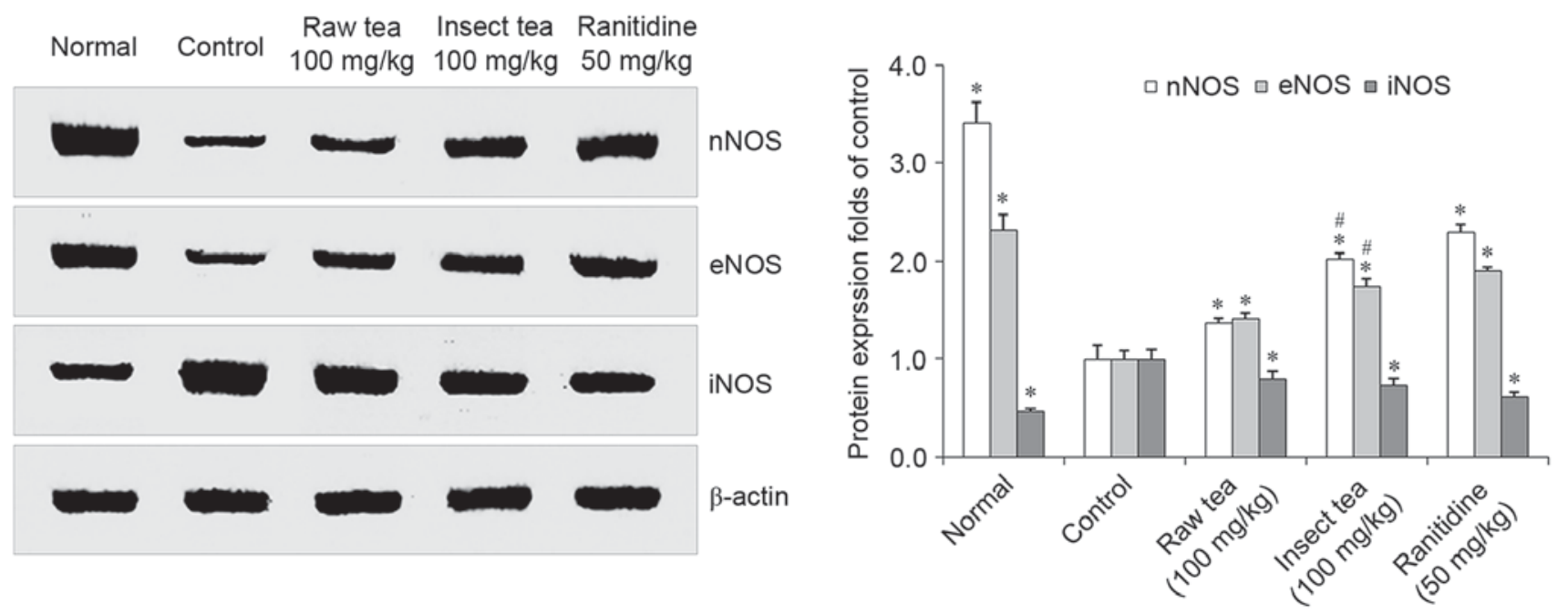

Figure 4. Effect of insect tea on nNOS, eNOS and iNOS protein expression in $\mathrm{HCl} /$ ethanol-induced gastric mucosal injury mice. Data are relative to the control group and are presented as the mean + standard deviation $(\mathrm{n}=7)$. ${ }^{\text {}} \mathrm{P}<0.05$ vs. control, ${ }^{\#} \mathrm{P}<0.05$ vs. raw tea. $\mathrm{n}$, neuronal; NOS, nitric oxide synthase; $\mathrm{e}$, endothelial; i, inducible.

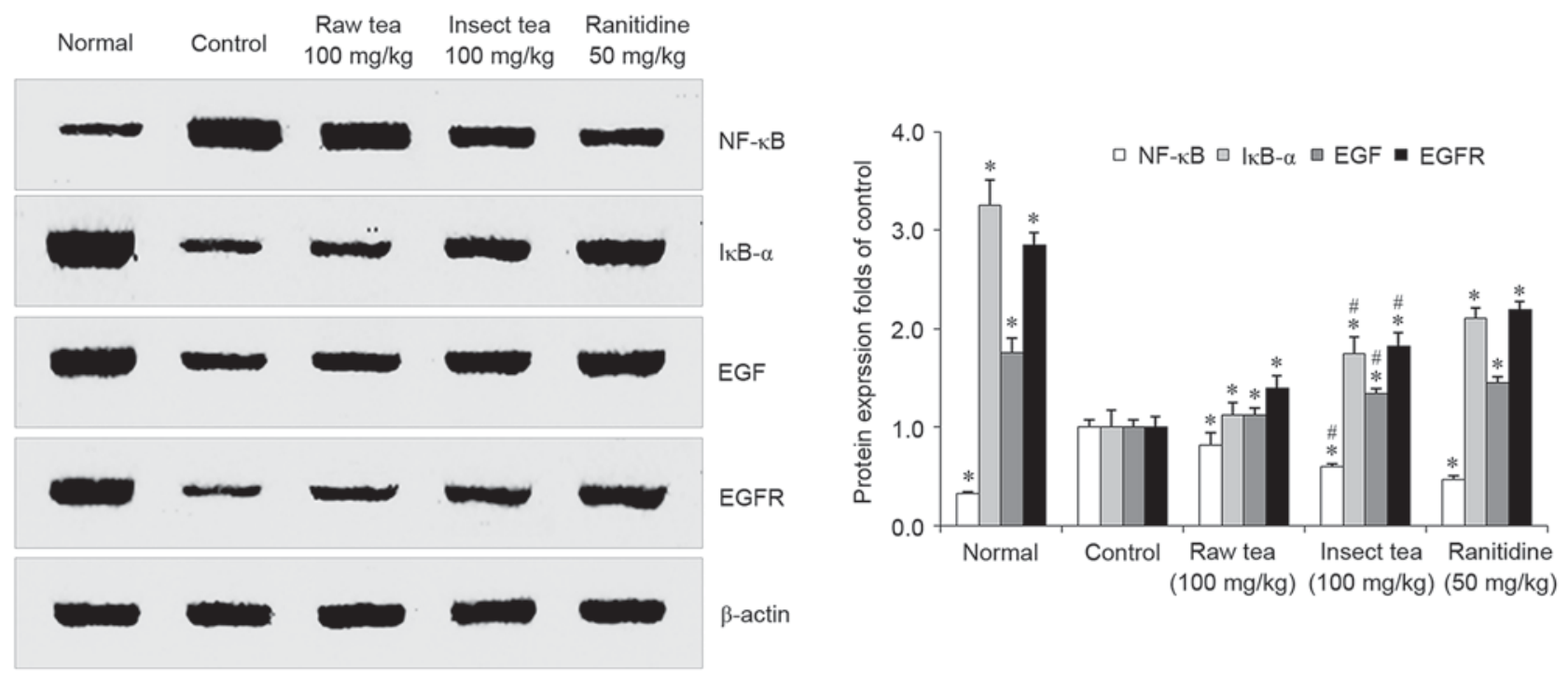

Figure 5. Effect of insect tea on NF-кB, IкB- $\alpha$, EGF and EGFR protein expression in $\mathrm{HCl} /$ ethanol-induced gastric mucosal injury mice. Data are relative to the control group and are presented as the mean + standard deviation $(\mathrm{n}=7)$. ${ }^{*} \mathrm{P}<0.05$ vs. control, ${ }^{\prime \prime} \mathrm{P}<0.05$ vs. raw tea. NF- $\kappa \mathrm{B}$, nuclear factor- $\kappa \mathrm{B}$; I $\mathrm{kB}-\alpha$, inhibitor of NF-кB; EGF, epidermal growth factor; EGFR, EGF receptor. 
of gastric ulcers (45-47). The administration of SOD has been reported to significantly protect against gastric mucosal injury (48). In the present study, administration of insect tea was observed to increase total SOD enzyme activity and the levels of Mn-SOD and $\mathrm{Cu} / \mathrm{Zn}$-SOD proteins in gastric ulcer mice. Insect tea also significantly increased the level of CAT in gastric mice. In a previous study, combined treatment with SOD and CAT was reported to reduce gastric lipid peroxidation levels in indomethacin-treated gastric ulcers in rats (47). In the present study, insect tea treatment significantly decreased the $\mathrm{HCl}$ /ethanol-induced generation of gastric MDA, which is one of the final products of lipid peroxidation and is widely used as an indicator to evaluate levels of tissue damage (49).

NO is a gas signaling molecule generated from NOS, and has been reported to serve a beneficial role during gastric ulcer healing in animals (50). There are three subtypes of NOS in human gastric mucosa, namely nNOS, iNOS and eNOS (51). In the present study, insect tea treatment significantly increased the gastric levels of $\mathrm{NO}$ and enhanced the protein expressions of nNOS and eNOS in gastric tissues. Insect tea also reduced the iNOS protein expression in ulcer mice. The low concentration of NO produced by eNOS has been observed to reduce gastric juice secretion, promoting wound healing by increasing blood flow and angiogenesis and protecting the gastric mucosa in gastric ulcer models $(52,53)$. Increased expression of eNOS promotes ulcer healing via its effects on angiogenesis in the gastric tissue of rats $(54,55)$.

$\mathrm{NF}-\kappa \mathrm{B}$ is a classic inflammation-associated protein that promotes inflammatory diseases and cancer (56). In the present study, insect tea treatment reduced the gastric levels of $\mathrm{NF}-\kappa \mathrm{B}$ protein in mice. Increasing the protein expressions of $\mathrm{I} \kappa \mathrm{B}-\alpha$, which is a cytoplasmic inhibitor of $\mathrm{NF}-\kappa \mathrm{B}$, reduces the inflammatory reaction and carcinogenesis in gastric disease (57). Insect tea treatment significantly increased the gastric protein expression of $\mathrm{I} \kappa \mathrm{B}-\alpha$ in the present study.

EGF stimulates cell growth, proliferation and differentiation by binding to EGFR, which is secreted by the salivary glands, Brunner's glands in the duodenum and pancreas (58). In the present study, insect tea treatment significantly increased the levels of EGF and EGFR in the gastric tissue of ulcer mice. Under normal physiological conditions, EGF inhibits gastric acid secretion, reducing the activity of gastric protease, promoting gastric epithelial cell proliferation and preventing ulcer formation $(58,59)$. EGF also accelerates healing in gastric ulcers by promoting cell DNA synthesis in the gastric mucosa $(59,60)$.

In conclusion, the results of the present study demonstrate that insect tea exhibits a protective effect against $\mathrm{HCl} /$ ethanol-induced gastric ulcers in ICR mice. Insect tea administration was able to attenuate $\mathrm{HCl} /$ ethanol-induced gastric acid secretion and increase the $\mathrm{pH}$ of gastric juice. Treatment with insect tea also modulated serum levels of MOT, SP, VIP, SS, and ET-1, and increased the activity of antioxidant enzymes to reduce lipid peroxidation in gastric tissues. In addition, insect tea modulated the protein expressions of iNOS, nNOS, and eNOS, and promoted NO secretion to protect the

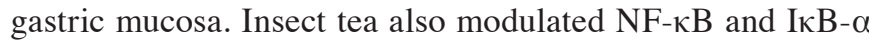
to reduce the inflammatory reaction and increased the gastric expressions of EGF and EGFR in the gastric mucosa of mice. These results indicate that the potential mechanism underlying the protective effects of insect tea may involve reducing gastric juice secretion, modulating neuropeptides, and regulating antioxidant activity and inflammatory reactions in the gastric mucosa. Insect tea represents a potential beneficial agent for the prevention of $\mathrm{HCl} /$ ethanol-induced gastric ulcers in vivo.

\section{Acknowledgements}

The present study was supported by the Construction Program of Chongqing Engineering Research Center (grant no. cstc2015yfpt_gcjsyjzx0027), the Scientific Research Foundation for Returned Overseas Chinese Scholars, State Education Ministry [grant no. Jiaowaisiliu (2014)1685], the Program for Innovation Team Building at Institutions of Higher Education in Chongqing (grant no. CXTDX201601040) and the Introduction of High-level Personnel Research Start-up Fund of Chongqing University of Education (grant no. 2013BSRC001).

\section{References}

1. Malfertheiner P, Chan FK and McColl KE: Peptic ulcer disease. Lancet 374: 1449-1461, 2009.

2. Hsu CC, Hsu YC, Chang KH, Lee CY, Chong LW, Lin CL, Shang CS, Sung FC and Kao CH: Depression and the risk of peptic ulcer disease: A nationwide population-based study. Medicine (Baltimore) 94: e2333, 2015.

3. Gyires K: Neuropeptides and gastric mucosal homeostasis. Curr Top Med Chem 4: 63-74, 2004.

4. Chen CY and Tsai CY: Ghrelin and motilin in the gastrointestinal system. Curr Pharm Des 18: 4755-4765, 2012.

5. Long DM, Leonard AS, Story J and French LA: Hypothalamus and gastric ulceration: II. production of gastrointestinal ulceration by chronic hypothalamic Stimulation. Arch Neurol 7: 167-183, 1962.

6. Mejia A and Kraft WK: Acid peptic diseases: Pharmacological approach to treatment. Expert Rev Clin Pharmacol 2: 295-314, 2009.

7. Thomson AB, Sauve MD, Kassam N and Kamitakahara H: Safety of the long-term use of proton pump inhibitors. World J Gastroenterol 16: 2323-2330, 2010.

8. Zhao X, Wang R, Qian Y, Li G, Zhou Y and Sun P: In vivo preventive effects of insect tea on buccal mucosa cancer in ICR mice. J Cancer Res Ther 10:651-657, 2014.

9. Xu L, Pan H, Lei Q, Xiao W, Peng Y and Xiao P: Insect tea, a wonderful work in the Chinese tea culture. Food Res Int 53: 629-635, 2013.

10. Qian Y, Li GJ, Wang R, Zhou YL, Sun P and Zhao X: In vitro anticancer effects of insect tea in TCA8113 cells. J Cancer Res Ther 10: 1045-1051, 2014.

11. Ao C: Scavenging effects of sandy-tea ethanol extract on super oxide anion and hydroxyl radical. Meat Res 4: 60-64, 2010.

12. Zhao X, Wang Q, Qian Y and Song JL: Ilex kudingcha C.J. Tseng (Kudingcha) prevents $\mathrm{HCl} /$ ethanol-induced gastric injury in Sprague-Dawley rats. Mol Med Rep 7: 1613-1616, 2013.

13. Wen L, Guo H, Li J, Yin R and Duan Z: Analyse of thebiological safety and major chemical components of Sanye insect tea. J Hunan Agric Univ 22: 574-579, 1996.

14. Guo S, Xu W, Wen L, Huang Y and Wang F: The nutrient analysis and evaluation of Sanye insect-fermented tea. Chin Bull Entomol 45: 128-132, 2008.

15. Beauchamp RD, Townsend CM, Singh P, Glass EJ and Thompson JC: Proglumide, a gastrin receptor antagonist, inhibits growth of colon cancer and enhances survival in mice. Ann Surg 202: 303-309, 1985.

16. Brzozowski T, Konturek SJ, Sliwowski Z, Drozdowicz D, Zaczek M and Kedra D: Role of arginine, a substrate for nitric oxide-synthase, in gastroprotection and ulcer healing. J Gastroenterol 32: 442-452, 1997.

17. Yatabe J, Saito F, Ishida I, Sato A, Hoshi M, Suzuki K, Kameda T, Ueno S, Yatabe MS, Watanabe T and Sanada H: Lower plasma arginine in enteral tube-fed patients with pressure ulcer and improved pressure ulcer healing after arginine supplementation by arginaid water. J Nutr Health Aging 15: 282-286, 2011. 
18. Desneves KJ, Todorovic BE, Cassar A and Crowe TC: Treatment with supplementary arginine, vitamin $\mathrm{C}$ and zinc in patients with pressure ulcers: A randomized controlled trial. Clin Nutr 24: 979-987, 2005

19. Zhenyukh O, Civantos E, Ruiz-Ortega M, Sánchez MS, Vázquez C, Peiró C, Egido J and Mas S: High concentration of branched-chain amino acids promotes oxidative stress, inflammation and migration of human peripheral blood mononuclear cells via mTORC1 activation. Free Radic Biol Med 104: 165-177, 2017.

20. Zhang XJ, Chinkes DL and Wolfe RR: Leucine supplementation has an anabolic effect on proteins in rabbit skin wound and muscle. J Nutr 134: 3313-3318, 2004.

21. Alphin RS, Vokac VA, Gregory RL, Bolton PM and Tawes JW III: Role of intragastric pressure, $\mathrm{pH}$ and pepsin in gastric ulceration in the rat. Gastroenterology 73: 495-500, 1977.

22. Venables CW: Mucus, pepsin, and peptic ulcer. Gut 27: 233-238, 1986.

23. Yamamoto O, Okada Y and Okabe S: Effects of a proton pump inhibitor, omeprazole, on gastric secretion and gastric and duodenal ulcers or erosions in rats. Dig Dis Sci 29: 394-401, 1984.

24. Delaney JP, Cheng JW, Butler BA and Ritchie WP Jr: Gastric ulcer and regurgitation gastritis. Gut 11: 715-719, 1970.

25. Guth PH: Pathogenesis of gastric mucosal injury. Annu Rev Med 33: 183-196, 1982.

26. Sandor A, Kidd M, Lawton GP, Miu K, Tang LH and Modlin IM: Neurohormonal modulation of rat enterochromaffin-like cell histamine secretion. Gastroenterology 110: 1084-1092, 1996.

27. Xie XZ, Zhao ZG, Qi DS and Wang ZM: Assay of gastrin and somatostatin in gastric antrum tissues of children with chronic gastritis and duodenal ulcer. World J Gastroenterol 12 : 2288-2290, 2006

28. Geoghegan JG and Pappas TN: Central peptidergic control of gastric acid secretion. Gut 40: 164-166, 1997.

29. Taché Y, Garrick T and Raybould H: Central nervous system action of peptides to influence gastrointestinal motor function. Gastroenterology 98: 517-528, 1990.

30. Holzer P: Neural emergency system in the stomach. Gastroenterology 114: 823-839, 1998.

31. Erin N, Türker S, Elpek Ö and Yıldırım B: Differential changes in Substance P, VIP as well as neprilysin levels in patients with gastritis or ulcer. Peptides 35: 218-224, 2012.

32. Brown JC and Parkes CO: Effect on fundic pouch motor activity of stimulatory and inhibitory fractions separated from pancreozymin. Gastroenterology 53: 731-736, 1967.

33. Ruppin H, Domschke S, Domschke W, Wünsch E, Jaeger E and Demling L: Effects of 13-nle-motilin in man-inhibition of gastric evacuation and stimulation of pepsin secretion. Scand J Gastroenterol 10: 199-202, 1975.

34. Itoh Z, Honda R, Hiwatashi K, Takeuchi S, Aizawa I, Takayanagi R and Couch EF: Motilin-induced mechanical activity in the canine alimentary tract. Scand J Gastroenterol Suppl 39: 93-110, 1976

35. Yanagisawa M, Kurihara H, Kimura S, Tomobe Y, Kobayashi M, Mitsui Y, Yazaki Y, Goto K and Masaki T: A novel potent vasoconstrictor peptide produced by vascular endothelial cells. Nature 332: 411-415, 1988.

36. Lazaratos S, Kashimura H, Nakahara A, Fukutomi H, Osuga T, Urushidani T, Miyauchi T and Goto K: Gastric ulcer induced by submucosal injection of ET-1: Role of potent vasoconstriction and intraluminal acid. Am J Physiol 265: G491-G498, 1993.

37. Michida T, Kawano S, Masuda E, Kobayashi I, Nishimura Y, Tsujii M, Takei Y, Tsuji S, Nagano K, Fusamoto H, et al: Endothelin-1 in the gastric mucosa in stress ulcers of critically ill patients. Am J Gastroenterol 92: 1177-1181, 1997.

38. Masuda E, Kawano S, Nagano K, Tsuji S, Takei Y, Hayashi N, Tsujii M, Oshita M, Michida T, Kobayashi I, et al: Role of endogenous endothelin in pathogenesis of ethanol-induced gastric mucosal injury in rats. Am J Physiol 265: G474-G481, 1993.

39. Lloyd KC, Wang J, Aurang K, Grönhed P, Coy DH and Walsh JH: Activation of somatostatin receptor subtype 2 inhibits acid secretion in rats. Am J Physiol 268: G102-G106, 1995.

40. Aurang K, Wang J and Lloyd K: Somatostatin inhibition of acid and histamine release by activation of somatostatin receptor subtype 2 receptors in rats. J Pharmacol Exp Ther 281: 245-252, 1997.
41. Martinez V, Curi AP, Torkian B, Schaeffer JM, Wilkinson HA, Walsh JH and Taché Y: High basal gastric acid secretion in somatostatin receptor subtype 2 knockout mice. Gastroenterology 114: $1125-1132,1998$

42. Saadé NE, Abdallah LE, Barada KA, Atweh SF and Nassar CF Effects of intracerebral injections of VIP on jejunal alanine absorption and gastric acid secretion in rats. Regul Pept 55: 269-276, 1995

43. Nassar CF, Abdallah LE, Barada KA and Atweh SF and Saadé NE: Effects of intravenous vasoactive intestinal peptide injection on jejunal alanine absorption and gastric acid secretion in rats. Regul Pept 55: 261-267, 1995.

44. Yoshikawa T, Ueda S, Naito Y, Takahashi S, Oyamada H, Morita Y, Yoneta T and Kondo M: Role of oxygen-derived free radicals in gastric mucosal injury induced by ischemia or ischemia-reperfusion in rats. Free Radic Res Commun 7: 285-291, 1989.

45. Yoshikawa T, Naito $\mathrm{Y}$, Ueda S, Oyamada H, Takemura T, Yoshida N, Sugino S and Kondo M: Role of oxygen-derived free radicals in the pathogenesis of gastric mucosal lesions in rats. J Clin Gastroenterol 12 (Suppl 1): S65-S71, 1990.

46. Yoshikawa T, Naito Y, Kishi A, Tomii T, Kaneko T, Iinuma S, Ichikawa H, Yasuda M, Takahashi S and Kondo M: Role of active oxygen, lipid peroxidation, and antioxidants in the pathogenesis of gastric mucosal injury induced by indomethacin in rats. Gut 34: 732-737, 1993.

47. Itoh M and Guth PH: Role of oxygen-derived free radicals in hemorrhagic shock-induced gastric lesions in the rat. Gastroenterology 88: 1162-1167, 1985.

48. Jung HK, Lee KE, Chu SH and Yi SY: Reactive oxygen species activity, mucosal lipoperoxidation and glutathione in Helicobacter pylori-infected gastric mucosa. J Gastroenterol Hepatol 16: 1336-1340, 2001

49. Akiba Y, Nakamura M, Mori M, Suzuki H, Oda M, Kimura H, Miura S, Tsuchiya $M$ and Ishii $\mathrm{H}$ : Inhibition of inducible nitric oxide synthase delays gastric ulcer healing in the rat. J Clin Gastroenterol 27 (Suppl 1): S64-S73, 1998.

50. Rajnakova A, Goh PM, Chan ST, Ngoi SS, Alponat A and Moochhala S: Expression of differential nitric oxide synthase isoforms in human normal gastric mucosa and gastric cancer tissue. Carcinogenesis 18: 1841-1845, 1997.

51. Barrachina M, Esplugues J, Martinezcuesta M, Calatayud S, Bello R and Wittle B: Nitric-oxide donors preferentially inhibit neuronally stimulated gastric-acid secretion. Gastroenterology: 47, 1994.

52. Takeuchi K, Ohuchi T and Okabe S: Nitric-oxide mediates inhibition of gastric-acid secretion in the damaged stomach-interaction with endogenous prostaglandins. In: Gastroenterology. pp192, 1994.

53. Ma L and Wallace JL: Endothelial nitric oxide synthase modulates gastric ulcer healing in rats. Am J Physiol Gastrointest Liver Physiol 279: G341-G346, 2000.

54. Guo JS, Cho CH, Wang WP, Shen XZ, Cheng CL and Koo MW: Expression and activities of three inducible enzymes in the healing of gastric ulcers in rats. World J Gastroenterol 9: $1767-1771,2003$

55. Gambhir S, Vyas D, Hollis M, Aekka A and Vyas A: Nuclear factor kappa B role in inflammation-associated gastrointestinal malignancies. World J Gastroenterol 21: 3174-3183, 2015.

56. Yanai A, Maeda S, Shibata W, Hikiba Y, Sakamoto K, Nakagawa H, Ohmae T, Hirata Y, Ogura K Muto S, et al: Activation of IKappaB kinase and NF-kappaB is essential for Helicobacter pylori-induced chronic gastritis in Mongolian gerbils. Infect Immun 76: 781-787, 2008.

57. Brzozowski T, Konturek SJ, Majka J, Dembinski A and Drozdowicz D: Epidermal growth factor, polyamines, and prostaglandins in healing of stress-induced gastric lesions in rats. Dig Dis Sci 38: 276-283, 1993.

58. Konturek JW, Bielanski W, Konturek SJ, Bogdal J and Oleksy J: Distribution and release of epidermal growth factor in man. Gut 30: 1194-1200, 1989.

59. Reeves J, Richards R and Cooke T: The effects of intracolonic EGF on mucosal growth and experimental carcinogenesis. Br J Cancer 63: 223-226, 1991.

60. Challacombe DN and Wheeler EE: Trophic action of epidermal growth factor on human duodenal mucosa cultured in vitro. Gut 32: 991-993, 1991. 